\title{
Evaluasi Penerapan Sistem Informasi Akuntansi Penjualan pada PT. Ciputra Internasional Manado
}

\author{
Oleh:
Judhistia P. J. Baramuli
Herman Karamoy

\author{
Program Pendidikan Profesi Akuntansi \\ Fakultas Ekonomi dan Bisnis \\ Universitas Sam Ratulangi Manado \\ Email:dizty_baramuli@yahoo.com
}

\begin{abstract}
ABSTRAK
Aktivitas bisnis properti merupakan aktivitas bisnis yang bergengsi dan menjanjikan bagi para pengusaha. Bisnis property bukanlah bisnis sederhana, bisnis ini besar dan kompleks, ditambah dengan semakin banyak pelaku bisnis yang memilih untuk menekuni bisnis ini, itu artinya persaingan semakin ketat. Oleh karena itu sangat penting bagi suatu perusahaan termasuk didalamnya perusahaan property, untuk menerapkan suatu sistem informasi yang relevan sesuai dengan kebutuhan perusahaan itu sendiri. Terutama dalam masalah keuangan perusahaan. Keuangan merupakan bagian yang vital dalam perusahaan, karenanya pengelolaan keuangan sangat mempengaruhi keberlangsungan hidup perusahaan. Penelitian ini dilakukan pada salah satu anak perusahaan ternama di Indonesia yang ada di Manado,yaitu PT. Ciputra Internasioanal Manado. Hasil penelitian ini menyatakan bahwa penerapan sistem informasi akuntansi yang dijalankan perusahaan telah cukup memadai, disamping itu terdapat Struktur Pengendalian Intern yang baik (terkandung unsur lingkungan pengendalian yan baik, aktivitas pengendalian dan pengawasan yang baik).
\end{abstract}

Kata Kunci: Sistem Informasi Akuntansi, Akuntansi Penjualan

\section{ABSTRACT}

The property business activity is a prestigious and promising business for entrepreneurs. Business property is not a simple business, this large and complex business, many people are choosing to pursue this business, it means that the competition is getting tougher. It is therefore very important for a company including the property's company, to implement a relevant information system according to the needs of the company itself. Especially in the company's financial problems. Finance is a vital part of the company, hence financial management greatly affect the survival of the company.

This study was conducted at one of Indonesia's leading subsidiaries in Manado, namely PT. Ciputra International Manado. The results of this study show that implementation of accounting information systems that run the company adequate, besides that there is a good Internal Control Structure (contained elements of good control environment, control activities and monitoring well).

Keywords: Accounting Information System 


\section{PENDAHULUAN}

\section{A. Latar Belakang Penelitian}

Informasi merupakan hal yang penting bagi perusahaan, baik itu perusahaan besar maupun perusahaan kecil. Informasi membantu mereka untuk mengetahui kondisi kondisi apapun yang terjadi baik yang terjadi di masa lalu maupun dimasa kini bahkan mungkin yang akan terjadi dimasa yang akan datang. Meski demikian, tidak semua informasi bermanfaat bagi perusahaan. Hanya informasi informasi tertentu saja yang dibutuhkan dan yang relevan yang perlu diperoleh perusahaan. Oleh karena itu perlu adanya sistem informasi yang dapat mengatur semua informasi yang ada sehingga informasi yang diperoleh lebih terarah dan tepat sasaran. Sebagai bagian dari perusahaan besar, tentunya PT. Ciputra Internasional Manado memiliki sistem informasi akuntansi yang dirancang sesuai dengan kebutuhan perusahaan. Dalam laporan akhir ini akan coba dilakukan evaluasi tentang bagaimana penerapan sistem informasi akuntansi khususnya penjualan dalam proses bisnis PT. Ciputra Internasional Manado, dengan mengangkat judul " Evaluasi Penerapan Sistem Informasi Akuntansi Penjualan pada PT. Ciputra Internasional Manado" untuk mengetahui seperti apa sistem Informasi akuntansi yang diterapkan oleh perusahaan dalam kegiatan penjualan dan mengevaluasi apakah sistem dan prosedur akuntansi penjualan yang dijalankan sudah memadai atau belum.

\section{B. Rumusan Masalah} Manado?

Bagaimana penerapan Sistem Informasi akuntansi penjualan pada PT. Ciputra Internasional

\section{Tujuan Penelitian}

Untuk mengevaluasi bagaimana efektifitas penerapan sistem informasi akuntansi penjualan PT. Ciputra Internasional Manado.

\section{Manfaat Penelitian}

Dari sisi manfaat teoritisnya, manfaat dari penelitian ini antara lain yaitu :

1. Diharapkan hasil dari penelitian ini dapat memberikan kontribusi positif bagi pengembangan ilmu pengetahuan khususnya bidang ekonomi akuntansi.

2. Penelitian ini dapat menjadi referensi bagi peneliti-peneliti selanjutnya yang juga merasa tertarik dengan penelitian ini, sehingga akan semakin sempurna dan lebih relevan sesuai dengan perubahanperubahan yang terjadi seiring dengan perkembangan ilmu pengetahuan dan teknologi.

Selanjutnya, dipandang dari sisi manfaat praktis, manfaat penelitian ini adalah:

1. Bagi manajemen, penelitian ini diharapkan dapat bermanfaat untuk menjadi acuan bagi pelaksanaan operasi perusahaan selanjutnya sehingga dapat memberikan solusi ataupun bahan pertimbangan bagi kemajuan dan masa depan perusahaan yang lebih baik.

2. Penelitian ini bermanfaat sebagai sarana mempraktekkan apa yang telah penulis peroleh selama menempuh pendidikan ekonomi akuntansi, selanjutnya menambah pengalaman serta pengetahuan secara konkret lewat penelitian langsung dilapangan.

\section{TINJAUAN PUSTAKA}

\section{A. Pengertian Informasi}

Informasi adalah data yang diolah menjadi bentuk yang lebih berguna dan lebih berarti bagi yang menerimanya, sedangkan data merupakan sumber informasi yang menggambarkan suatu kejadian (kumpulan fakta). Informasi terdiri dari data yang telah ditransformasi dan dibuat lebih bernilai melalui pemrosesan.

Menurut Longkutoy dalam Sutabri (2012) istilah data adalah suatu istilah majemuk yang berarti fakta atau bagian dari fakta yang mengandung arti yang dihubungkan dengan kenyataan, simbol-simbol, gambargambar, angka-angka, huruf-huruf yang menunjukkan suatu ide, objek, kondisi, atau situasi dan lain lain. 
Jelasnya data itu bisa berupa apa saja dan dapat ditemui dimana saja. Kegunaan data adalah sebagai bahan dasar yang objektif (relatif) didalam proses kebijakan dan keputusan oleh pimpinan organisasi.

\section{B. Pengertian Sistem Informasi}

Sistem adalah rangkaian dari dua atau lebih komponen-komponen yang saling berhubungan, yang berinteraksi untuk mencapai suatu tujuan. Tujuan dasar suatu sistem tergantung pada jenis sistem itu sendiri. Secara sederhana, suatu sistem dapat diartikan sebagai suatu kumpulan atau himpunan dari unsur, komponen, atau variabel yang terorganisir, saling berinteraksi, saling tergantung satu sama lain, dan terpadu.

Sistem informasi adalah aplikasi untuk mendukung operasi dari suatu organisasi: operasi, instalasi, dan perawatan komputer, perangkat lunak, dan data. Sistem informasi manajemen adalah kunci dari bidang yang menekankan finansial dan personal manajemen. Sistem Informasi Penjualan adalah suatu sistem informasi yang mengorganisasikan serangkaian prosedur dan metode yang dirancang untuk menghasilkan, menganalisa, menyebarkan dan memperoleh informasi guna mendukung pengambilan keputusan mengenai penjualan.

\section{Pengertian Sistem Informasi Akuntansi}

Menurut Bodnard dan Hopwood (2000:23) sistem informasi akuntansi adalah kumpulan sumber daya seperti manusia dan peralatan yang diatur untuk mengubah data menjadi informasi.

Menurut Hall (2008) dalam bukunya Accounting Information System, " the information system is the set of formal procedures by which data are collected, processed into information, and distributed to users".

\section{Tujuan Penyusunan Sistem Informasi Akuntasi}

Tujuan umum penyusunan sistem informasi akuntansi adalah sebagai berikut:

a. Untuk memperbaiki informasi yang diberikan oleh sistem dalam kualitas, ketepatan waktu atau struktur dari informasi tersebut.

b. Untuk memperbaiki pengendalian akuntansi dan pengecekan intern, yang berarti memperbaiki daya andal informasi akuntansi dan menyediakan catatan yang lengkap sebagai pertanggungjawaban dalam melindungi harta perusahaan.

c. Untuk menurunkan biaya dalam menyelenggarakan catatan akuntansi.

2. Manfaat Sistem Informasi Akuntansi

a. Mengamankan harta/kekayaan perusahaan Harta kekayaan meliputi kas perusahaan, persediaan barang dagangan, termasuk aset tetap perusahaan.

b. Menghasilkan beragam informasi untuk pengambilan keputusan

Perusahaan membutuhkan informasi yang mudah diakses yang hanya dapat terjadi apabila sistem informasi perusahaan tersebut dirancang dengan baik, sehingga perusahaan dapat melakukan pengambilan keputusan dengan tepat dari informasi yang dihasilkan.

c. Menghasilkan informasi untuk pihak eksternal

Dengan sistem informasi yang baik pihak perusahaan dapat dengan mudah mengetahui besarnya pajak yang harus dibayar, atau pihak eksternal seperti bank dapat dengan mudah menentukan besarnya utang yang dapat diberikan.

d. Menghasilkan informasi untuk penilaian kinerja karyawan atau divisi

Sistem informasi dapat juga dimanfaatkan untuk penilaiankinerja karyawan atau divisi. Apresiasi pada karyawan yang rajin berguna untuk memotivasi karyawan dan meminimalkan sikap malas-malasan di tempat kerja.

e. Menyediakan data masa lalu untuk kepentingan audit (pemeriksaan)

Data yang tersimpan dengan baik sangat memudahkan proses audit. Data data yang sudah lama namun yang penting bagi perusahaan sewaktu waktu dibutuhkan untuk keperluan audit, oleh karena itu sangat peru bagi perusahaan membuat sistem infaormasi yang baik.

f. Menghasilkan informasi untuk penyusunan dan evaluasi anggaran perusahaan 
Anggaran merupakan alat yang sering digunakan perusahaan untuk mengendalikan pengeluaran kas. Sistem informasi dapat dirancang untuk mempermudah pengawasan pengeluaran, apakah sudah melewati batas anggaran yang telah disetujui.

g. Menghasilkan informasi yang diperlukan dalam kegiatan perencanaan dan pengendalian.

\section{Sistem Informasi Akuntansi Penjualan}

Menurut Ikatan Akuntansi Indonesia dalam SAK yaitu, penjualan barang meliputi barang yang diproduksi perusahaan untuk dijual dan barang yang dibeli untuk dijual kembali, seperti barang dagang yang dibeli pengecer atau tanah dan properti lain yang dibeli untuk dijual kembali. Sistem informasi akuntansi penjualan adalah sub sistem informasi bisnis yang mencakup kumpulan prosedur yang melaksanakan, mencatat, mengkalkulasi, membuat dokumen dan informasi penjualan untuk keperluan manajemen dan bagian lain yang berkepentingan, mulai dari diterimanya order penjualan sampai mencatat timbulnya tagihan/piutan dagang.

\section{Systems Flowchart}

Systems flowchart adalah penyajian secara grafis dari sistem informasi dan sistem operasi yang terkait. Sistem informasi disini meliputi proses, aliran logis, input, output, dan arsip. Sedangkan sistem operasi yang terkait mencakup entitas, aliran fisik, dan kegiatan operasi.

\section{Sistem Pengendalian Internal}

Pengendalian internal adalah semua rencana organisasional, metode, dan pengukuran yang dipilih oleh suatu kegiatan usaha untuk mengamankan harta kekayaannya, mengecek keakuratan dan keandalan data akuntansi usaha tersebut, meningkatkan efisiensi, operasional, dan mendukung dipatuhinya kebijakan manajerial yang telah ditetapkan.

COSO (the Committee of Sponsoring Organization) mendefinisikan pengendalian internal sebagai proses yang diimplementasikan oleh dewan direksi, manajemen serta seluruh staf dan karyawan dibawah arahan mereka dengan tujuan untuk memberikan jaminan yang memadai atas tercapainya tujuan pengendalian. Tujuan pengendalian tersebut meliputi; efektivitas dan efisiensi operasi, reliabilitas pelaporan keuangan, dan kesesuaian dengan aturan dan regulasi yang ada. Selain itu terdapat lima unsur dalam model pengendalian COSO, yaitu :

a. Lingkungan pengendalian

b. Aktivitas pengendalian

c. Penilaian risiko (Risk Assesment)

d. Informasi dan Komunikasi

e. Pengawasan Kinerja

\section{METODE PENELITIAN}

\section{A. Jenis Penelitian}

Penelitian kali ini merupakan jenis penelitian replikasi penelitian sebelumnya, dimana pernah ada penelitian serupa, namun pada objek dan waktu yang berbeda.

\section{B. Tempat dan Waktu Penelitian}

Penelitian ini dilakukan di kantor pemasaran PT. Ciputra Internasional Manado, yang beralamat di Kecamatan Pineleng Kompleks perumahan Citraland Manado. Penelitian dilakukan sejak bulan Mei hingga bulan Desember tahun 2013.

\section{Prosedur Penelitian}

Proses penelitian ini diawali dengan pembuatan proposal awal penulisan laporan akhir yang menekankan pada judul laporan akhir. Setelah disetujui, dilanjutkan dengan pembuatan surat permohonan penelitian untuk perusahaan yang menjadi objek penelitian, dimana surat dibuat dan ditandatangani pihak fakultas. Selanjutnya diserahkan kepada kepada perusahaan untuk di disposisi. Setelah mendapat disposisi dari perusahaan, penelitian dimulai, dan diawali dengan wawancara ke bagian marketing, kemudian 
pengambilan data berupa profil perusahaan. Wawancara dilakukan tiga kali pada waktu yang berbeda, namun ada beberapa kali perusahaan meminta pertanyaan dalam bentuk tulisan saja. Selanjutnya data-data yang diperoleh dari hasil wawancara dan daftar pertanyaan, dianalisis, dan diolah menjadi data tertulis dalam Bab III pembahasan, kemudaian ditarik kesimpulan dan saran yang tertuang pada Bab IV laporan akhir ini.

\section{Metode Pengumpulan Data}

\section{Jenis Data}

Jenis data yang digunakan dalam penelitian ini adalah data kualitatif yang diperoleh dari respon tertulis dan wawancara langsung pada pihak marketing PT. Ciputra Internasional Manado.

\section{Sumber Data}

Sumber data yang digunakan dalam penelitian ini adalah data primer dan data sekunder. Data-data tersebut diperoleh langsung dari pihak marketing PT. Ciputra Internasional Manado dan tinjauan kepustakaan serta searching internet

\section{Teknik Pengumpulan Data}

Penelitian ini menggunakan metode pengumpulan data penelitian kepustakaan dan penelitian lapangan, serta menggunakan teknik pengumpulan data pertanyaan tulisan dan interview.

\section{E. Metode Analisis}

Metode analisis data yang digunakan adalah metode analisis deskriptif. Dimana penulis menguraikan apa yang menjadi persoalan, dalam hal ini uraian tentang bagaimana sistem informasi akuntansi penjualan yang diterapkan oleh perusahaan dan kemudian mengevaluasinya berdasarkan teori yang ada.

\section{HASIL PENELITIAN DAN PEMBAHASAN}

\section{A. Pembahasan}

\section{Sistem Informasi Akuntansi Penjualan}

Diawali dengan costumer yang akan membeli rumah, ditawarkan berbagai pilihan atau tipe rumah yang diinginkan. Costumer akan didampingi oleh sales yang akan terus berurusan dengan costumer selama proses pembelian rumah. Setelah costumer menentukan pilihan rumah yang diinginkan, costumer akan diarahkan oleh sales ke bagian kasir untuk membayar tanda jadi sebesar Rp. 10.000.000, pembayaran bisa langsung dilakukan pada hari itu juga atau bisa juga pada hari lain yang sudahditentukan costumer dan disepakati bersama. Setelah pembayaran tanda jadi dilakukan, bagian kasir akan menerbitkan kwitansi tiga rangkap, masing-masing untuk costumer dan untuk arsip di kasir dan untuk bagian keuangan. Jika pada suatu waktu costumer batal membeli rumah maka uang tanda jadi yang sudah dibayarkan tidak dapat diambil kembali. Selanjutnya setelah costumer membayar tanda jadi dan mendapat kwitansi tanda pemabayaran sudah dilakukan, sales akan memberikan SPT dan SPPJB yang diterbitkan oleh bagian Marketing Support dan Departemen Legal untuk ditanda tangani oleh costumer. SPT dan SPPJB terdiri dari empat rangkap, yang pertama untuk costumer sendiri, kedua untuk bagian marketing, ketiga untuk bagian collection (penagih) dan keempat untuk bagian akuntansi atau keuangan. Selanjutnya pada waktu yang sudah ditentukan dan disepakati customer akan diarahkan lagi oleh sales ke kasir untuk membayar uang Downpayment (DP) sesuai dengan ketentuan perusahaan yang membagi 3 jenis pembayaran yaitu : Cash, 30\% dari harga rumah; KPR 10\% dari harga rumah (tipe $<70 \mathrm{~m}$ ), dan 30\% dari harga rumah (tipe $>70 \mathrm{~m}$ ); dan yang ketiga adalah jenis Inhouse, 30\% dari harga rumah. Bagian kasir akan kembali menerbitkan kwitansi tanda pembayaran DP suadah dilakukan sejumlah tiga rangkap, masing-masing untuk bagian kasir, bagian keuangan dan untuk costumer sebagai pegangan bukti pembayaran untuk proses selanjutnya. Setelah pembayaran DP, dilanjutkan dengan dengan pembayaran terakhir yaitu pemabayaran cash atau angsuran untuk jenis KPR dan Inhouse. Kasir akan kembali menerbitkan kwitansi dua rangkap, untuk costumer dan kasir. Selanjutnya pada hari itu juga kasir akan menyerahkan seluruh uang hasil transaksi sepanjang hari itu kepada pihak Bank, dan seluruh kwitansi yang diterbitkan 
diserahkan kepada bagian akuntansi, untuk kemudian dicatat, diarsip, dan dibuatkan laporan disetiap periodenya. Bagian kasir juga akan membuat laporan penerimaan kas harian berdasarkan hasil pembayaran costumer hari itu.

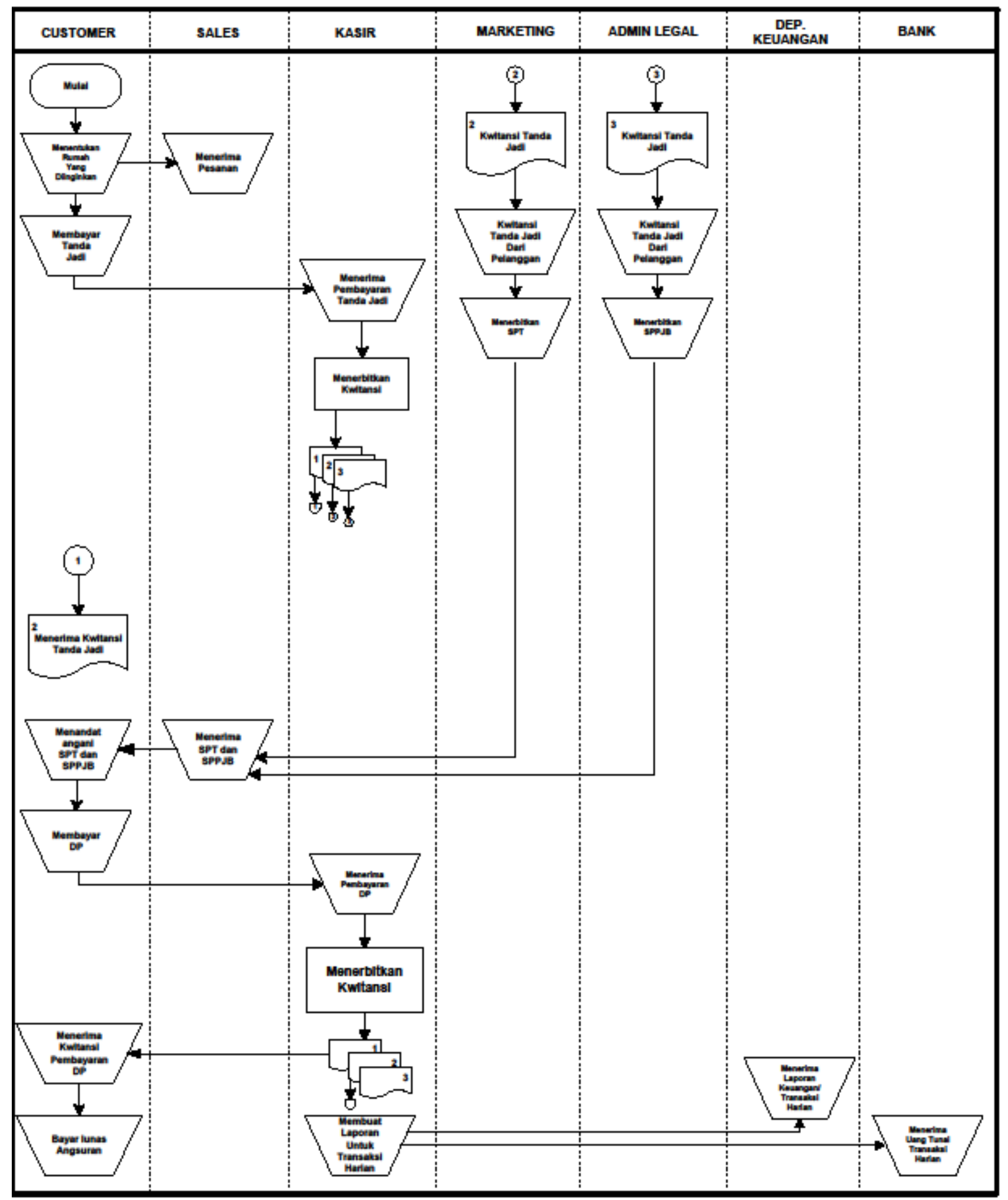




\section{Pengendalian Internal PT. Ciputra Internasional Manado}

a. Lingkungan Pengendalian (Control Environment)

manajemen menekankan pentingnya bersikap etis, baik terhadap pelanggan atau kepada siapapun yang berkepentingan dengan pelanggan, maupun terhadap sesama rekan kerja didalam perusahaan. Atasan juga memberi contoh kepada karyawan, baik dalam hal etika, integritas, kedisiplinan kerja dan sikap menghargai. Manajemen juga menyusun struktur organisasi untuk menegaskan mengenai pembagian wewenang dan otoritas, serta membuat deskripsi pekerjaan untuk mempertegas tanggung jawab masing-masing. Perekrutan karyawan dilakukan sesuai dengan posisi yang dibutuhkan perusahaan, mengikuti tes kompetensi sehungga karyawan dipastikan sesuai dengan posisi yangdibutuhkan dan memiliki kretifitas dan inisiatif dalam pekerjaannya. Selain itu karyawan juga di berikan pelatihan-pelatihan sesuai dengan kebutuhan pekerjaan mereka, serta dilakukan evaluasi mengenai kinerja karyawan tersebut dalam bentuk Performance Apprisal (PA). Hasil atau skor yang diperoleh dala PA tersebut menjadi dasar bagi manajemen untuk memberikan penghargaan baik berupa bonus, kenaikan gaji, atau kenaikan golongan.

b. Aktivitas Pengendalian ( Control Activity)

Aktivitas pengendalian yang diterapkan PT. Ciputra Internasional Manado antara lain berupa desain dokumen yang baik dimana dokumen-dokumen yang dibuat sederhana, jelas, dan dapat dimengerti sehingga meminimalkan kemungkinan kesalahan mengisi. Selanjutnya, adanya pemisahan tugas antara fungsi penyimpan harta/kas, dengan fungsi pencatat, dan fungsi otorisasi transaksi bisnis. Selain itu, adanya otorisasi yang memadai atas setiap transaksi bisnis yang terjadi. Manajemen juga melakukan pengecekan independen atas pekerjaan karyawan, misalnya adanya aturan melakukan rekonsiliasi antara buku bank menurut catatan perusahaan dengan rekening koran dari Bank, kemudian ada pula pengecekan cashflow, dan pengadaan cash opname setiap hari, selain itu ada pula pembuatan laporan penerimaan kas harian yang dibuat oleh bagian kasir yang akan diserahkan ke bagian akuntansi beserta dengan dokumen-dokumen pendukung lainnya.

c. Penilaian Resiko (Risk Assesment)

Manajemen melakukan penilaian resiko yang bisa mengancam kelangsungan operasi perusahaan, dengan menerapkan sistem informasi akuntasi yang sesuai dan relevan dengan kebutuhan perusahaan agar data keuangan perusahaan dapat diolah dengan benar dan menghasilkan informasi yang berkualitas serta pengendalian yang layak dapat diterapkan.

d. Informasi dan Komunikasi (Information and communication)

Manajemen menyadari pentingnya memiliki catatan keuangan yang valid. Untuk itu manajemen merancang sistem informasi akuntansi untuk mendukung validitas catatan keuangan dan memperoleh informasi yang tepat dan relevan.

e. Pengawasan Kinerja (Performance Monitoring)

Dalam hal pengawasan kinerja, perusahaan menerapkan model sistem informasi pertanggungjawaban seperti adanya laporan kinerja yang membandingkan kinerja aktual dengan rencana. Perusahaan juga menerapkan kebijakan pelaksanaan Morning Briefing antara pimpinan dan karyawan, media ini sebagai dasar evaluasi program kerja yang sudah dilaksanakan dan perencanaan untuk program kerja selanjutnya. Ada pula aktivitas pengawasan dan evaluasi laporan keuangan serta kondisi keuangan perusahaan oleh Financial Controller.

\section{Bagian - Bagian yang Terkait dalam Sistem Penjualan}
a. Bagian Sales
b. Bagian Kasir
c. Bagian Departemen Legal
d. Bagian Marketing Support 
e. Bagsian Keuangan/ Akuntansi

\section{Dokumen yang Digunakan dalam Sistem Penjualan}

a. Kwitansi Tanda Jadi

b. Kwitansi Downpayment

c. Kwitansi Pembayaran Cash atau Angsuran

d. Bukti setor Bank

e. SPT (Surat Pemesanan Tanah)

f. SPPJB (Surat Perjanjian Pengikatan Jual Beli)

\section{Catatan Akuntansi yang digunakan dalam Sistem Penjualan}
a. Jurnal Penjualan
b. Laporan Kas Kecil
c. Laporan Penerimaan Retribusi dan Angsuran
d. Jurnal Umum
e. Jurnal Penerimaan Kas

\section{Evaluasi Penerapan Sistem Informasi Penjualan}

Kebaikan :

a. Adanya pemisahan fungsi, tugas dan tanggung jawab yang jelas

b. Adanya laporan yang dibuat oleh masing-masing departemen untuk mempertanggung jawabkan tugas / peran mereka

c. Adannya pemberlakuan "Opname Cash" setiap hari

d. Adanya rekonsiliasi antara buku bank menurut catatan perusahaan dengan rekening koran dan bank

e. Adanya proses pengikatan yang meyakinkan tentang adanya kepastian pembelian melalui pembayaran tanda jadi terlebih dahulu.

Kekurangan:

a. Catatan keuangan seperti kwitansi dari kasir, semuanya dilimpahkan / diserahkan kepada bagian keuangan tanpa ada yang diarsip dikasir.

b. Perusahaan tidak menerapkan pengasuransian dalam perjalanan, sementara dana yang biasa masuk relatif besar

c. Tidak adanya batasan jumlah uang tunai yang bisa dipegang oleh bagian keuangan.

\section{KESIMPULAN DAN SARAN}

\section{A. Kesimpulan}

Setelah mengetahui dan mengevaluasi penerapan Sistem Informasi Akuntansi Penjualan pada PT. Ciputra Internasional Manado, maka dapat ditarik kesimpulan bahwa:

1. Penerapan sistem dan prosedur akuntansi penjualan yang dijalankan perusahaan telah cukup memadai.

2. Terdapat struktur pengendalian intern yang baik (terkandung unsur lingkungan pengendalian yang baik, aktivitas pengendalian dan pengawasan yang baik).

3. Bagian kasir tidak bertugas menyimpan kwitansi bukti pembayaran, karena semuanya diserahkan ke bagian keuangan.

\section{B. Saran}

1. Untuk pengamanan kas seharusnya ada pengasuransian kas yang ada ditangan dan kas yang ada diperusahaan serta kas dalam perjalanan, mengingat jumlah penerimaan kas dan pengeluaran kas relatif besar setiap hari.

2. Baik jumlah uang tunai yang dipegang, diberi batasan tertentu melalui kebijakan perusahaan untuk menghindari penyalahgunaan kas ditangan. 
3. Agar dibuat suatu program aplikasi yang dapat menghubungkan satu departemen ke departemen yang lain, dimana aplikasi ini dibakukan dan hanya dapat dioperasikan oleh orang-orang tertentu yang berwenang agar informasi setiap transaksi atau kejadian dalam perusahaan dapat cepat diperoleh dan efisien, menghindari juga penyalahgunaan wewenang.

4. Untuk penerbitan kwitansi pembayaran tanda jadi sebaiknya dibuat 4 rangkap, selain untuk costumer, kasir, dan Bagian Keuangan/Akuntansi, juga untuk Departemen Legal/ Marketing Support.

\section{DAFTAR PUSTAKA}

Baridwan, Zaki. 2004. Sistem Akuntansi. BPFE Yogyakarta.

Bodnar, George H. William S Hopwood. 2004. Accounting Information Systems. Ninth Edition. Pearson Prentice Hall.

Davis, Gordon B. 1999. Kerangka Dasar Sistem Informasi Manajemen Bagian I; Pengantar Diterjemahkan oleh Andreas S. Adiwardana. Cetakan kesebelas. PT. Ikrar Mandiri Abadi.

Hall, James A. 2008. Accounting Information System. Sixth Edition. South Western Cengage Learning.

Horngren, Charles T. et.al. 2008. Akuntansi Biaya: Penekanan Manajerial. Edisi 11. Jilid 1. Indeks. Jordan, Ross Westerfield. 2009. Pengantar Keuangan Perusahaan. Edisi 8. Buku 2. Salemba Empat. Joseph, Wilkinson W. 1993. Sistem Akunting dan Informasi; diterjemahkan oleh Ir. Agus Maulana,MSM. Edisi ketiga. Jild satu. Binarupa Aksara.

Laudon, Kenneth C. 2005. Sistem Informasi Akuntansi. Salemba Empat. Prianthara, Ida Bagus Teddy. 2010. Sistem Akuntansi Perusahaan Jasa Konstruksi. Graha Ilmu. Romney, Marshall B. Paul John Steinbart, 2004. Accounting Information Systems. Ninth Edition. Salemba Empat.

Santoso, Iman. 2010. Akuntansi Keuangan Menengah. Buku 1. Refika Aditama.

Standar Akuntansi Keuangan. 2012. Ikatan Akuntansi Indonesia (IAI).

Suhayati, Ely. Sri Dewi Anggadini. 2009. Akuntansi Keuangan. Graha Ilmu.

Sutabri, Tata. 2012. Konsep Sistem Informasi, Penerbit Andi.

Tunggal, Amin Widjaja. 2012. Pengantar Akuntansi Perusahaan. Harvarindo. 